\title{
The growth of pediatric neurosurgery in southern Vietnam and the first separation of pygopagus twins: case report
}

\author{
Dang D. T. Can, MD, ${ }^{1,9}$ Jacob R. Lepard, MD, $, 1,2,8$ Tran T. Tri, MD, ${ }^{4}$ Tran Van Duong, MD, ${ }^{5}$ \\ Nguyen T. Thuy, MD, ${ }^{6}$ Pham N. Thach, MD, ${ }^{7}$ James M. Johnston, MD, ${ }^{2,3}$ W. Jerry Oakes, MD, ${ }^{2,3}$ and \\ Tran Dong A, MD4
}

\begin{abstract}
${ }^{1}$ Neurosurgical Department, Children's Hospital 2, and 'University of Medicine and Pharmacy at Ho Chi Minh City, Vietnam; 2Department of Neurological Surgery, University of Alabama at Birmingham; ${ }^{3}$ Section of Pediatric Neurosurgery, Children's of Alabama, Birmingham, Alabama; 'Pediatric Surgery Department, Children's Hospital 2, Ho Chi Minh City; ${ }^{5}$ Plastic Surgery

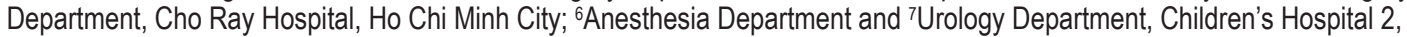
Ho Chi Minh City, Vietnam; and ${ }^{8}$ Harvard Program for Global Surgery and Social Change, Harvard Medical School, Boston, Massachusetts
\end{abstract}

Conjoined twins are a rare congenital abnormality with an estimated incidence of 1:50,000 pregnancies and 1:200,000 live births. Pygopagus twins are characterized by sacrococcygeal fusion that is commonly associated with perineal and spinal abnormalities. Management of this complex disease requires a well-developed surgical system with multidisciplinary capacity and expertise.

A decade ago there were no dedicated pediatric neurosurgeons in southern Vietnam. This has changed within a few short years; there are now 10 dedicated pediatric neurosurgeons with continually expanding technical capacity. In August 2017 a multidisciplinary surgical and anesthetic team successfully separated female pygopagus twins with fused sacrum and spinal cord with associated myelomeningocele defect.

The authors present here the first successful separation of pygopagus twins in Vietnam as a representative case of gradual and sustainable pediatric neurosurgical scale-up.

https://thejns.org/doi/abs/10.3171/2019.11.PEDS19291

KEYWORDS global neurosurgery; pygopagus; conjoined twins; Vietnam; limited resources; pediatric neurosurgery; congenital

$\mathrm{C}$ ONJOINED twins are a rare congenital abnormality with an estimated incidence of 1:50,000 pregnancies and 1:200,000 live births and a known female predilection of 3:1. ${ }^{30}$ Pygopagus twins represent 6\%-19\% of conjoined twins and are characterized by sacrococcygeal fusion that is commonly associated with perineal and spinal abnormalities. ${ }^{16}$ Although rare, they represent a complex surgical pathology often requiring expertise in obstetrics, ${ }^{3,9,16}$ pediatric surgery, $, 8,18,19,34$ urology, ${ }^{11,13}$ neurosurgery, ${ }^{7,28}$ plastic surgery, ${ }_{14}^{14}$ anesthesia, ${ }^{24,26,32}$ radiology, and critical care. ${ }^{12}$ Because of the need for nuanced multidisciplinary care, the successful management of these cases has often been limited to well-equipped centers in developed countries with extensive surgical and neurosurgical capacity. ${ }^{8,19,22,28}$ Thus, the occurrence of these complex pathologies in lower-resource settings necessitates either referral and transfer to centers in more developed countries $^{27}$ or investment and scale-up in local surgical capacity. Only the latter is a sustainable option. Indeed, the Lancet Commission on Global Surgery (LCoGS) reports that 5 billion people lack access to safe and affordable surgical care when needed, ${ }^{15}$ with much of the unmet burden being neurosurgical ${ }^{20}$ and pediatric neurosurgical disease. ${ }^{5}$ Based on this, we present here the first successful separation of pygopagus twins in Vietnam as a representative case of gradual and sustainable pediatric neurosurgical scale-up.

\section{Case Report}

Presentation and Workup

The 2 female patients were born on July 23, 2016, in 


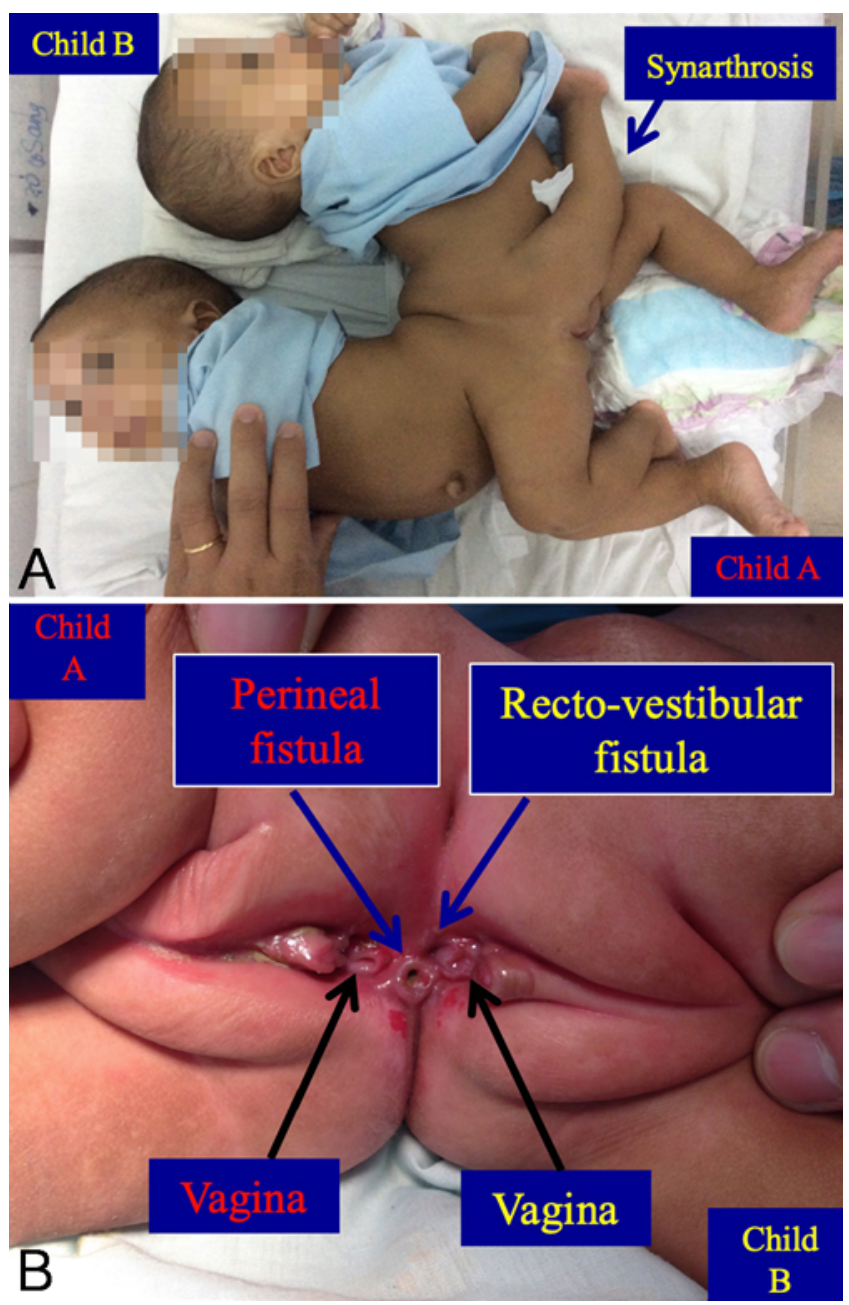

FIG. 1. Physical examination of the twins demonstrating sacrococcygeal fusion (A) and perineal abnormalities (B). Figure is available in color online only.

Binh Phuoc province, a rural area of southern Vietnam. The primigravid mother was 18 years old and gave birth at 33 weeks via cesarean section at a provincial hospital. She had undergone no antenatal care. The total birth weight was $3.4 \mathrm{~kg}$. Four days later the twins were transferred to Children's Hospital 2 (CH2) in Ho Chi Minh City for evaluation. On initial examination they were noted to have fused backs and buttocks. Perineal examination demonstrated separate vaginas with a perineal fistula in the case of child A and a rectovestibular fistula in the case of child B. Synarthrosis of the right knee was noted in child B, as well as congenital hip dysplasia (Fig. 1). Neurological examination demonstrated no abnormalities for child A and paraplegia for child B. Urodynamics were not available. Abdominal ultrasound demonstrated no evidence of bladder or ureter dilation. CT was performed, which demonstrated a fused sacrum with intact spinal lamina in child $\mathrm{A}$ and spinal laminar defects with associated myelomeningocele in child B (Fig. 2A and B). MRI confirmed the presence of myelomeningocele in child $\mathrm{B}$ and spinal fusion in the proximal sacrum resulting in a single thecal sac and conjoined spinal cord tethered by a fatty filum distally (Fig. 2C and D). Cardiopulmonary evaluation revealed no abnormalities. There was no shared vascularity and all abdominal and pelvic organs were found to be separate.

\section{Surgical Management}

The decision was made to delay separation until the twins were older and could better tolerate the procedure. The surgery was ultimately scheduled for August 2017. The patients were 13 months old at this time with a combined weight of $12 \mathrm{~kg}$. Tissue expanders were implanted 1 month prior to surgery but were complicated by infection and subsequently removed without being used. The multidisciplinary team consisted of neurosurgery, pediatric surgery, plastic surgery, and anesthesia, which were separated into a "red" and "yellow" team with focus on child A and child B, respectively (Fig. 3A). The surgical plan was divided into 4 phases (Table 1).

Phase 1 involved the skin flap and soft-tissue dissection and was performed by a combination of plastic surgery and neurosurgery. The patients were placed in the lateral position with the first operative side (side 1) facing up and the second operative side (side 2) facing down. Both sides were prepared simultaneously and side 2 was kept sterile by laying the patients on a sterile sheet prior to surgical draping (Fig. 3B). Using Doppler ultrasonography to identify vascular pedicles, the first M-shaped skin flap was marked to provide sufficient skin coverage to both patients postoperatively. The superficial tissue dissection was completed by the plastic surgery team. Following this the neurosurgical team exposed the myelomeningocele of child B and the lamina of both children, performing laminectomies as needed to fully visualize the thecal sac proximal and distal to the point of fusion. Phase 2 required exploration of the 2 spinal cords with dissection of the fused cord, myelomeningocele, and filum. The neural placode of child $\mathrm{B}$ was released from the dura mater of child A and the fatty filum of the fused segment was detethered. Next, the conjoined cord was separated-with preference given to preserve child A's normal motor function. This was completed under microscopic visualization (Fig. 4). Last, the dura of child A and the neural placode and dura of child $\mathrm{B}$ were closed in watertight fashion. Neurophysiological monitoring is not currently available at $\mathrm{CH} 2$ and was not used in this case (Video 1).

VIDEO 1. Summary of patient presentation and steps of the procedure. Copyright Jacob R. Lepard. Published with permission. Click here to view.

In phase 3 the patients were rotated $180^{\circ}$ to facilitate complete separation of the perineum. This was accomplished by obtaining hemostasis, packing the surgical wound on side 1 , and then removing the outer surgical drapes to expose the underlying sterile sheet. A sterile plastic bag was then placed and sealed with tape so that it contained the legs and lower trunks of both patients as well as the packed surgical wound. Then with involvement of both red and yellow surgical and anesthesia teams the patients were carefully rotated $180^{\circ}$ so that side 1 was facing the underlying sterile sheet and side 2 was facing up. Following this an identical M-shaped incision was made on side 2 and the perineal dissection was done so that the 

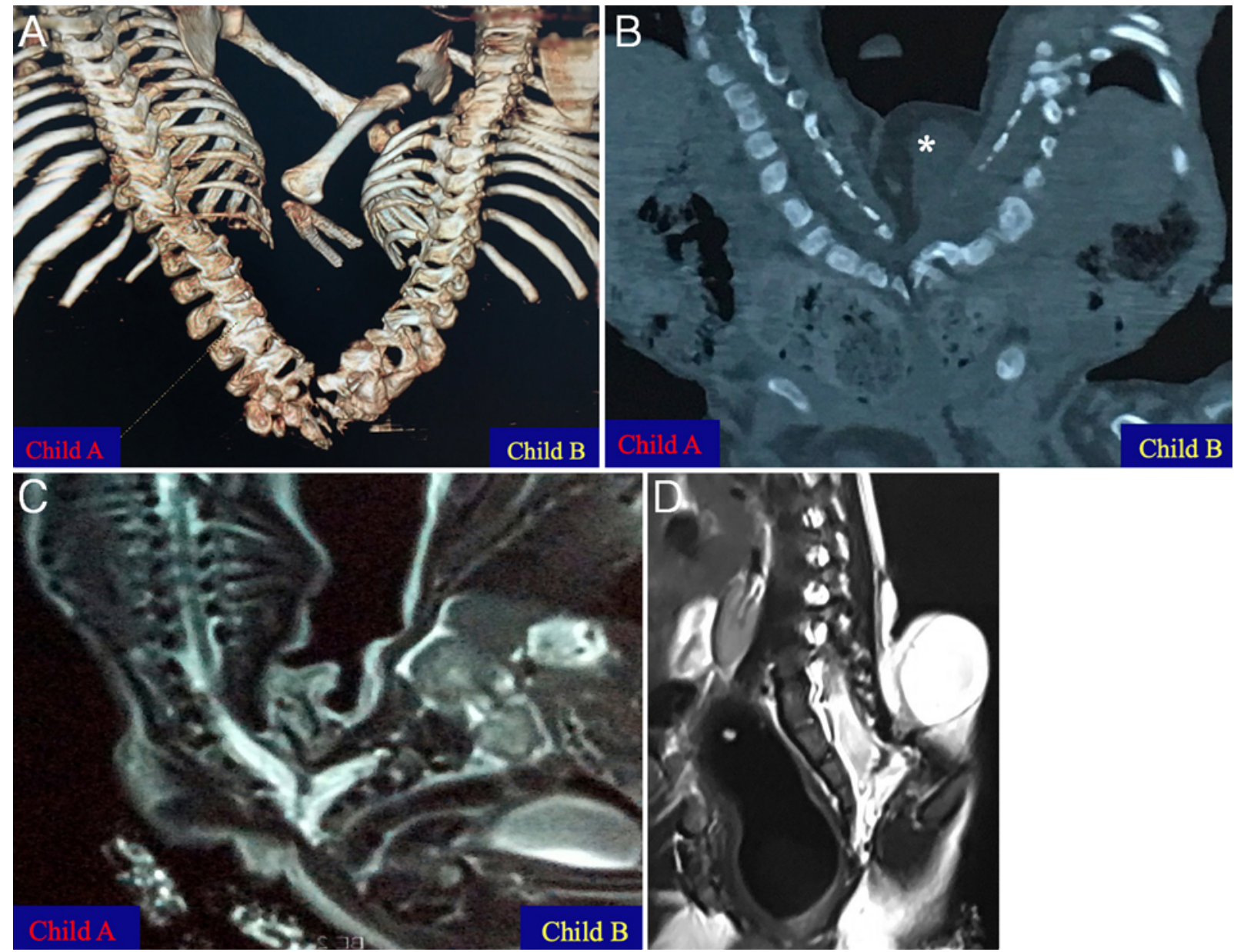

FIG. 2. A: 3D CT reconstruction of sacrococcygeal fusion. B: Sagittal CT demonstrating intact lamina of child $A$ and laminar defects with associated myelomeningocele (asterisk) of child B. C: Sagittal T2-weighted MRI sequence demonstrating distal spinal cord fusion and tethering. D: Sagittal T2-weighted MRI sequence showing the myelomeningocele defect in child 2. Figure is available in color online only.

twins were separated completely. In phase 4 each patient was placed prone in separate but adjacent operating rooms and underwent a rotational myofascial gluteal flap followed by interlocking closure of the $2 \mathrm{M}$-shaped skin flaps in each patient. Finally, the patients were rotated to the supine position for a diverting colostomy by the pediatric surgery team to conclude the procedure.

\section{Outcome and Follow-Up}

Postoperatively the patients retained their baseline level of neurological function, with child A having no new motor deficits or incontinence. Child B remained paraplegic without bladder continence, which was unchanged from prior to surgery. At the 2-week follow-up child A was found to have a CSF leak. This was treated with surgical exploration followed by temporary ventricular and lumbar drainage and subsequently resolved without requiring further intervention. The children continue to have scheduled outpatient follow-up with all surgical providers to ensure continued improvement and to observe for delayed complications. At 1 year after surgery the patients are doing well at home and meeting appropriate developmental milestones.

\section{Discussion}

\section{The Growth of Pediatric Neurosurgery in Vietnam}

Neurosurgery in Vietnam was jointly founded by Dr. Nguyen Thuong Xuan in Hanoi in 1956 and by Dr. Dang Van Chieu in 1958 in Ho Chi Minh City (Saigon). ${ }^{1}$ Over the following decades Vietnamese neurosurgery has expanded significantly with 2 high-volume neurosurgical training centers in the north and south based out of Viet Duc Hospital in Hanoi and Cho Ray Hospital in Ho Chi Minh City, respectively. ${ }^{10}$ As of now there are an estimated 600 neurosurgeons serving Vietnam's population of $90,728,900$, giving a density of 0.661 neurosurgeons per 100,000 population (see https://www.wfns.org/menu/61/ global-neurosurgical-workforce-map). Despite this growth there has been limited expansion of pediatric neurosurgical expertise, with the majority of pediatric neurosurgical capacity being based in the northern region at Hanoi's National Hospital of Pediatrics. In 2011 the first dedicated pediatric neurosurgical department in southern Vietnam was established by Dr. Dang Do Thanh Can at the $\mathrm{CH} 2$ in Ho Chi Minh City. 

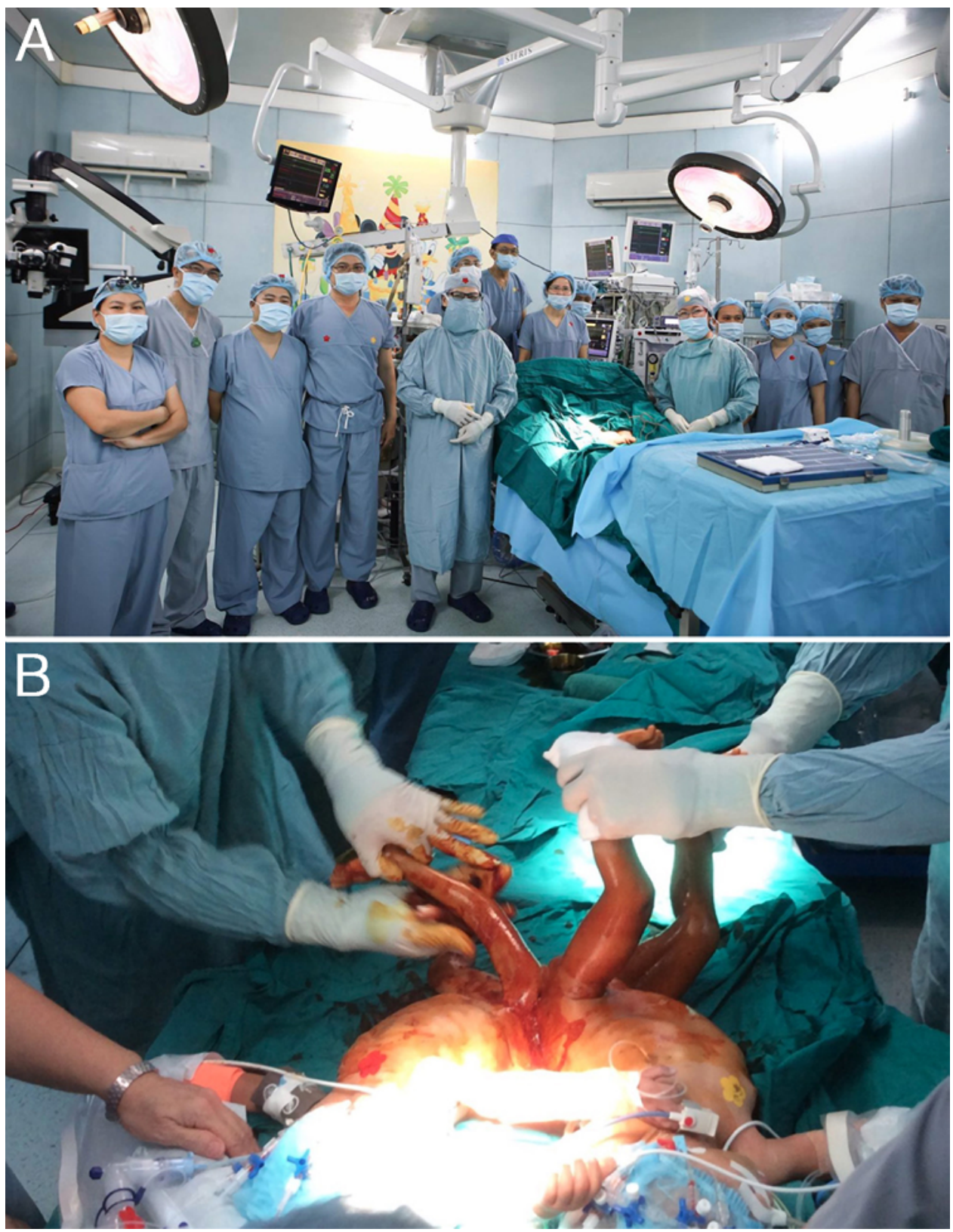

FIG. 3. A: The multidisciplinary surgical and anesthetic team. B: Side 1 and side 2 being prepped simultaneously on sterile sheets prior to draping. Figure is available in color online only.

Initially, the procedural capacity was limited to trauma and basic management of tumor, hydrocephalus, and vascular disease due to a lack of microsurgical equipment. In just 8 short years the department has expanded to include 10 dedicated pediatric neurosurgeons with 2 operative microscopes and the capability of performing complex microsurgical dissection of intraventricular and pineal region tumors, arteriovenous malformations, and advanced craniofacial pathology. Through consistent mentorship and partnerships with outside institutions such as the University of Alabama at Birmingham, ${ }^{21}$ Ochsner Medical Center, and CURE International, ${ }^{6}$ the technical capabilities have grown to include surgical treatment of refractory epilepsy, complex vascular dis- ease, craniofacial surgery, and flexible endoscopy for pediatric hydrocephalus. Currently the department of pediatric neurosurgery at $\mathrm{CH} 2$ performs 600 procedures per year, with 400 categorized as elective and 200 as emergency procedures.

\section{Surgical Separation in Resource-Limited Settings}

It is estimated that only 25 separations of pygopagus twins have been performed to date, ${ }^{35}$ with several described in resource-limited settings. Indeed, other cases of successful pygopagus separation have been reported from low- and middle-income countries such as Nigeria, ${ }^{1}$ Rwanda, ${ }^{17}$ India, ${ }^{19}$ and the Phillipines ${ }^{25}$ Additionally, sev- 
TABLE 1. Summary of the surgical plan divided by phase, specifying participating surgical teams and goals of each phase

\begin{tabular}{|c|c|c|}
\hline Phase & Surgical Teams & Goals \\
\hline 1 & $\begin{array}{c}\text { Plastic Surgery \& } \\
\text { Neurosurgery }\end{array}$ & $\begin{array}{l}\text { 1. First M-shaped skin flap on side } 1 \\
\text { 2. Dissection from skin to muscle (Plas- } \\
\text { tic Surgery) } \\
\text { 3. Exposure of dural sac \& meningocele } \\
\text { defect (Neurosurgery) }\end{array}$ \\
\hline 2 & Neurosurgery & $\begin{array}{l}\text { 1. Exploration of both spinal cords, } \\
\text { filum, \& myelomeningocele } \\
\text { 2. Release the neural placode of child B } \\
\text { from surrounding dura } \\
\text { 3. Detether the conjoined fatty filum } \\
\text { 4. Separate the fused cord } \\
\text { 5. Close all dural sacs }\end{array}$ \\
\hline 3 & $\begin{array}{l}\text { Pediatric Surgery \& } \\
\text { Plastic Surgery }\end{array}$ & $\begin{array}{l}\text { 1. Obtain hemostasis \& pack surgical } \\
\text { wound } \\
\text { 2. } 180^{\circ} \text { rotation } \\
\text { 3. Second M-shaped skin flap on side } 2 \\
\text { 4. Final separation of perineum \& trans- } \\
\text { fer to separate operating rooms }\end{array}$ \\
\hline 4 & $\begin{array}{c}\text { Plastic Surgery \& } \\
\text { Neurosurgery }\end{array}$ & $\begin{array}{l}\text { 1. Rotate the twins to prone position } \\
\text { 2. Rotational myofascial gluteal flap } \\
\text { 3. Closure of skin incisions in interlock- } \\
\text { ing fashion } \\
\text { 4. Rotate the twins to supine position } \\
\text { 5. Diverting colostomy }\end{array}$ \\
\hline
\end{tabular}

eral large series exist from well-equipped and highly experienced centers such as Cape Town in South Africa ${ }^{22}$ and São Paulo in Brazil. ${ }^{31}$ Notably, one separation of ischiopagus twins has been previously undertaken in Vietnam. ${ }^{33}$ However, our current case is unique from this prior report due to the extensive CNS involvement and necessity of pediatric neurosurgical expertise.

There were several technical aspects of the case that increased the complexity from a neurosurgical perspective. First, the presence of the myelomeningocele defect in child B made the dissection significantly more difficult. Awasthi et al. reported a case of pygopagus twins with spina bifida; however, the extent of the defect was limited to bony abnormalities without the presence of a myelomeningocele. ${ }^{2}$ In our case the myelomeningocele was ultimately managed with microneurosurgical dissection followed by standard dural reconstruction and closure (Video 1). Next was the ethical deliberation regarding which twin should be given preference in terms of functional neurological tissue. Ethical concerns regarding conjoined twins are not uncommon. ${ }^{29}$ However, the discussion necessary to reach a mutual decision between the family and medical team is challenging in a developing world setting in which there is limited lay understanding of the capabilities and limitations of medical care.

Last, it is significant that this case was managed entirely by the team of Vietnamese surgeons without assistance from foreign surgeons. The unique effort of choreographing and rehearsing each stage of the procedure among multiple surgical specialties and teams sets a new
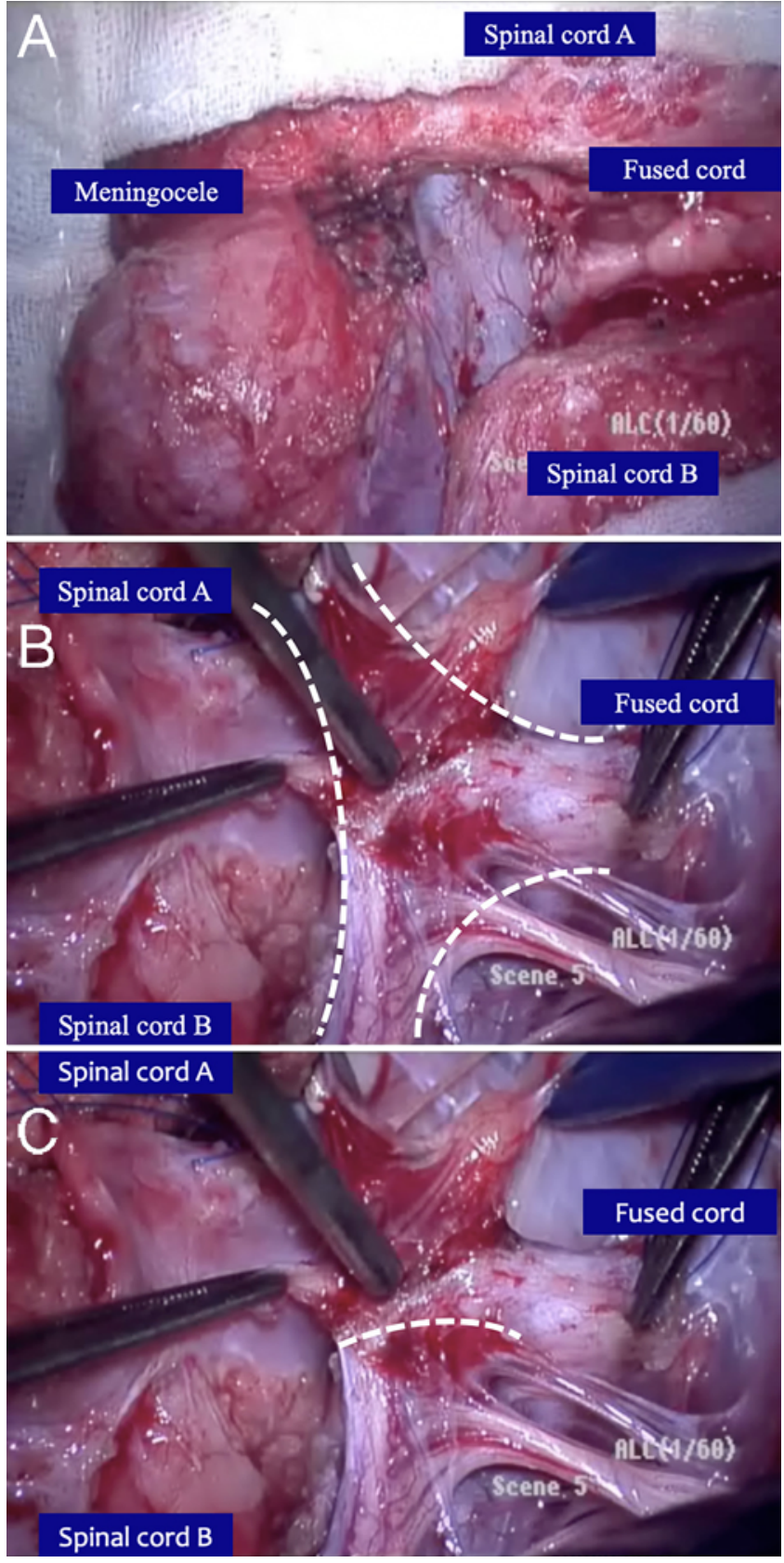

FIG. 4. Intraoperative views. A: Exposure of the meningocele and conjoined thecal sac. B: Opened dura revealing cord fusion. C: Plane of cord separation giving preference of functional tissue to the neurologically intact child $\mathrm{A}$ (dashed line). Figure is available in color online only.

standard of complexity for multidisciplinary surgical care in Vietnam. Although the surgical separation was an important accomplishment, the continued follow-up and long-term management of such patients is equally important. At 1 year postoperatively the follow-up mechanisms have worked well. However, this will need to be continued throughout the patients' childhood in order to prevent delayed complications related to urological and orthopedic sequelae. 


\section{Implications for Pediatric Neurosurgical Workforce}

The LCoGS recommends the availability of safe and affordable delivery of essential surgical procedures within 2 hours of home..$^{15}$ In the present case the twins were born in a neighboring province only 120 kilometers from Ho Chi Minh City. Although separation of pygopagus twins hardly represents "essential surgical care" in comparison to more commonly needed procedures such as laparotomy, cesarean section, or craniotomy, the capability of performing this operation nonetheless represents an important level of sophistication and overall surgical capacity for Vietnam. The multidisciplinary expertise displayed in this case speaks strongly to the successful scale-up of the surgical system as a whole. Another finding of the LCoGS is that 33 million individuals annually face catastrophic financial expenditure to pay for surgical and anesthesia care. ${ }^{15}$ By performing this procedure close to home and within the local medical system, the out-of-pocket care costs were negligible and the direct and indirect costs of traveling abroad for care were mitigated.

Regarding the pediatric neurosurgical aspects of the case, it is important to note that such an undertaking would not have been possible locally just 10 years prior. Indeed, an important publication in 1997 by Drs. Rosenfeld and Xuan, the latter one of the founders of neurosurgery in Vietnam, shed important light on the current local status of the field. ${ }^{23}$ The workforce at that time was described as having exceptional technical proficiency but with significant need of advanced surgical equipment and subspecialty mentorship. Xuan quite prophetically observed that "over the next decade, it is likely that, with strong international pressures, neurosurgery in Vietnam will develop rapidly into the microneurosurgery era." This case report, as well as countless other unreported cases, serves as fulfillment of that statement.

It is worth noting that the previous paradigm for care of such complex cases would involve the assistance and primary management by foreign surgeons or transporting the patient to have the procedure performed internationally. Neither option provides a sustainable solution to the local deficit of surgical expertise, and more immediately, no mechanism for cohesive follow-up and long-term care. The expansion of pediatric neurosurgical expertise to southern Vietnam represents an important landmark in neurosurgical coverage; however, there is still much work to be done in the country and surrounding region. Additionally, as neurosurgical expertise in countries like Vietnam and Thailand continues to develop and strengthen it will be important for that knowledge to spill over into surrounding countries like Laos and Myanmar, where the neurosurgical workforce is still in its foundational phases of growth.

\section{Conclusions}

The separation of pygopagus twins is a technically difficult procedure requiring multidisciplinary expertise. Its successful completion in southern Vietnam is a significant marker of effective and sustainable expansion of the surgical system as a whole. Pediatric neurosurgical expertise has expanded considerably in this region and should con- tinue to be a priority for the international neurosurgical community.

\section{Acknowledgments}

This study was completed while Jacob R. Lepard was a Wilson Family Clinical Scholar. Funding for international travel was provided by the Children's of Alabama Global Surgery Program (www.childrensal.org/global-surgery-program).

\section{References}

1. Adejuyigbe O, Sowande OA, Olabanji JK, Komolafe EO, Faponle F, Adetiloye VA, et al: Successful separation of two pairs of conjoined twins in Ile Ife, Nigeria: case reports. East Afr Med J 82:50-54, 2005

2. Awasthi R, Iyengar R, Rege S, Jain N: Surgical management of pygopagus conjoined twins with spinal bifida. Eur Spine J 24 (Suppl 4):S560-S563, 2015

3. Brizot ML, Liao AW, Lopes LM, Okumura M, Marques MS, Krebs V, et al: Conjoined twins pregnancies: experience with 36 cases from a single center. Prenat Diagn 31:1120-1125, 2011

4. Cook A, El-Gohary A, Khoury AE: The use of a threedimensional imaging model to optimize the operative separation of pygopagus conjoined twins. J Pediatr Urol 1:321-325, 2005

5. Dewan MC, Baticulon RE, Rattani A, Johnston JM, Warf BC, Harkness W: Pediatric neurosurgical workforce, access to care, equipment and training needs worldwide. Neurosurg Focus 45(4):E13, 2018

6. Dewan MC, Onen J, Bow H, Ssenyonga P, Howard C, Warf BC: Subspecialty pediatric neurosurgery training: a skillbased training model for neurosurgeons in low-resourced health systems. Neurosurg Focus 45(4):E2, 2018

7. Fieggen AG, Dunn RN, Pitcher RD, Millar AJW, Rode H, Peter JC: Ischiopagus and pygopagus conjoined twins: neurosurgical considerations. Childs Nerv Syst 20:640-651, 2004

8. Fowler CL, Pulito AR, Warf BC, Vandenbrink KD: Separation of complex pygopagus conjoined twins. J Pediatr Surg 34:619-622, 1999

9. Gul A, Aslan H, Ceylan Y: Prenatal diagnosis of pygopagus tetrapus parasitic twin: case report. BMC Pregnancy Childbirth 4:13, 2004

10. Karras CL, Tran HM, Dornbos D III, Nguyen P, Nimjee SM, Prevedello DM, et al: Inside Vietnam's largest neurosurgery department. World Neurosurg 105:122-125, 2017

11. Kim SS, Waldhausen JHT, Weidner BCS, Grady R, Mitchell M, Sawin R: Perineal reconstruction of female conjoined twins. J Pediatr Surg 37:1740-1743, 2002

12. Kobylarz K: Intensive care of conjoined twins. Anaesthesiol Intensive Ther 46:130-136, 2014

13. Lazarus J, Raad J, Rode H, Millar A: Long-term urological outcomes in six sets of conjoined twins. J Pediatr Urol 7:520-525, 2011

14. McDowell BC, Morton BE, Janik JS, Gerow RK, Handler MH, Lowenstein AD, et al: Separation of conjoined pygopagus twins. Plast Reconstr Surg 111:1998-2002, 2003

15. Meara JG, Leather AJM, Hagander L, Alkire BC, Alonso N, Ameh EA, et al: Global Surgery 2030: evidence and solutions for achieving health, welfare, and economic development. Lancet 386:569-624, 2015

16. Mian A, Gabra NI, Sharma T, Topale N, Gielecki J, Tubbs RS, et al: Conjoined twins: from conception to separation, a review. Clin Anat 30:385-396, 2017

17. Nyundo M, Jahn A, Kayondo K, Ntirenganya F, Muzungu K, Ntakiyiruta G, et al: Successful separation of conjoined pygopagus twins in African environment with limited resources. Rwanda Med J 69:47-50, 2012 
18. O'Neill JA Jr, Holcomb GW III, Schnaufer L, Templeton JM Jr, Bishop HC, Ross AJ III, et al: Surgical experience with thirteen conjoined twins. Ann Surg 208:299-312, 1988

19. Pai K M, Naidu RC, Raja A, Rai YS, Kumar N, Kini A, et al: Surgical nuances in the separation of craniopagus twinsour experience and a follow up of 15 years. Neurol India 66:426-433, 2018

20. Punchak M, Mukhopadhyay S, Sachdev S, Hung YC, Peeters S, Rattani A, et al: Neurosurgical care: availability and access in low-income and middle-income countries. World Neurosurg 112:e240-e254, 2018

21. Rocque BG, Davis MC, McClugage SG, Tuan DA, King DT, Huong NT, et al: Surgical treatment of epilepsy in Vietnam: program development and international collaboration. Neurosurg Focus 45(4):E3, 2018

22. Rode H, Fieggen AG, Brown RA, Cywes S, Davies MRQ, Hewitson JP, et al: Four decades of conjoined twins at Red Cross Children's Hospital-lessons learned. S Afr Med J 96:931-940, 2006

23. Rosenfeld JV, Xuan NT: Neurosurgery in Vietnam. Surg Neurol 48:307-311, 1997

24. Roy M: Anaesthesia for separation of conjoined twins. Anaesthesia 39:1225-1228, 1984

25. Saguil E, Almonte J, Baltazar W, Acosta A, Caballes A, Catangui A, et al: Conjoined twins in the Philippines: experience of a single institution. Pediatr Surg Int 25:775-780, 2009

26. Sara JP, Kydes A, Pryjdun O, Jacoby M, McBride W, Pandya $S$, et al: Anesthesia for pygopagus conjoined twins during single-twin and simultaneous pneumoperitoneum: a case report. A A Pract 11:71-72, 2018

27. Shija JK, Ngiloi PJ: Final stage surgical treatment of the conjoined twins of Masasi, Tanzania: case report. East Afr Med J 77:172-173, 2000

28. Spitz L: Conjoined twins. Prenat Diagn 25:814-819, 2005

29. Spitz L: Ethics in the management of conjoined twins. Semin Pediatr Surg 24:263-264, 2015

30. Spitz L, Kiely EM: Experience in the management of conjoined twins. Br J Surg 89:1188-1192, 2002
31. Tannuri ACA, Batatinha JAP, Velhote MCP, Tannuri U: Conjoined twins: twenty years' experience at a reference center in Brazil. Clinics (São Paulo) 68:371-377, 2013

32. Thomas JM, Lopez JT: Conjoined twins - the anaesthetic management of 15 sets from 1991-2002. Paediatr Anaesth 14:117-129, 2004

33. Tran DA: Successful separation of ischiopagus tripus conjoined twins with one twin suffering from brain damage. J Pediatr Surg 28:965-968, 1993

34. Votteler TP, Lipsky K: Long-term results of 10 conjoined twin separations. J Pediatr Surg 40:618-629, 2005

35. Winder M, Law A: Separation of pyopagus conjoined twins: a New Zealand neurosurgical experience. J Clin Neurosci 13:968-975, 2006

\section{Disclosures}

The authors report no conflict of interest concerning the materials or methods used in this study or the findings specified in this paper.

\section{Author Contributions}

Conception and design: Lepard, Can, Tri, Duong, Thuy, Thach, Dong A. Drafting the article: Lepard, Can. Critically revising the article: Johnston. Reviewed submitted version of manuscript: Can, Duong, Johnston, Oakes, Dong A.

\section{Supplemental Information \\ Videos}

Video 1. https://vimeo.com/374397520.

\section{Correspondence}

Jacob R. Lepard: University of Alabama at Birmingham, AL. jlepard@uabmc.edu. 